\title{
ABSTRACTS AND REVIEWS
}

\author{
BACTERIOLOGY.
}

Generad.

C. S. R. AYYAR. The use of small additions of acid for increasing the germicidal action of E.C. on bacterial spores. Agric. J. India, 25, 213-19, 1930. (Chem. Abst. 25, viii, 1865, April 20, 1931.)

Tests on a hypochlorite solution E.C. (containing 2 per cent. of available chlorine), showed that a mixed solution containing 0.2 per cent. E.C. and 0.05 per cent. $N$ citric acid destroyed the spores of $B$. subtilis, $B$. albolactus and $B$. mesentericus in $30 \mathrm{~min}$. With E.C. alone $(0.2$ per cent. solution) the spores were not destroyed after $60 \mathrm{~min}$., although the numbers were considerably reduced.

M. I. Cerristian

G. I. WaLlaCe and F. W. TANNER. Efiect of heat on mould spores. Proc. Soc. Exp. Biol. and Med. 28, ix, 970-2, June 1931.

The authors have studied the heat resistance of spores of Aspergillus niger, Oidium lactis, Mucor mirus, Rhizopus nigricans and Alternaria solani. Suspensions in 1,3 and 6 per cent. $\mathrm{NaCl}$ solution, 10, 25 and 50 per cent. sugar solution, juice from cherries in syrup, and distilled water were used for the tests. The results show that $60^{\circ} \mathrm{C}$. for $5 \mathrm{~min}$. is usually sufficient to ensure complete destruction of the spores. In some cases $A$ spergillus niger and Oidium lactis proved exceptional, since resistances of $60^{\circ} \mathrm{C}$. for $10 \mathrm{~min}$. and $30 \mathrm{~min}$. respectively were recorded. Neither the sugar nor salt solution appears to exert a protective or destructive influence. M. I. Christian

H. Fink and F. WEINFURTNER. Staining of yeast cells with methylene blue and its relation to hydrogen-ion concentration and permeability. Woch. Brau. 48, 159-62, 1931. (J. Inst. Brewing, 37, vi, 328, June 1931.)

Yeast cells are reported to take methylene blue more readily in alkaline than in acid solution. In the presence of sugars, normal living cells take the stain like dead cells, but show no loss of reproductive capacity. Dextrose, laevulose, cane sugar and galactose are about equally effective in increasing the permeability, whilst maltose is less so. These results indicate the need for revision of the methylene blue test for yeast.

M. I. Christian

D. MüLLER. Untersuchungen über Oxydasen in getöteten Essigbakterien. I. (Oxydases in dead acetic bacteria. I.) Biochem. Z. 238, 253-67, August 1931.

Acetone treated deposits of $B$. pasteurianum (Acetobacter pasteurianus) absorb oxygen slowly; addition of alcohols increases this uptake enormously. Ethyl alcohol is oxidised to acetic acid and n-propyl alcohol to propionic. Isopropyl alcohol is oxidised quantitatively to acetone, but this oxidation is inhibited by heating the preparation at $95^{\circ} \mathrm{C}$. for $30 \mathrm{~min}$.

J. G. DAVIS

C. E. A. WInsLOW and E. T. HAYwood. The specific potency of certain cations with reference to their effect on bacterial viability. J. Bact. 22, i, 49-69, July 1931.

This paper presents a detailed study of specific cation effects on a strain of $E$. coli. Considering the potency of $\mathrm{Na}$ as 1 , the following figures represent the activity of other cations: $\mathrm{K} 1, \mathrm{Li} 3, \mathrm{Ba} 5, \mathrm{Mg} 9, \mathrm{Ca} 12, \mathrm{Mn} 400, \mathrm{Zn} 700$, and $\mathrm{Cd} \mathrm{3000.} \mathrm{All}$ cations stimulate growth in low concentrations and inhibit at higher levels.

The authors suggest that the phenomena of specific potency agree with Bancroft's 
theory of disinfection, according to which disinfection is due to the coagulation of the cell colloids, the decreasing stability of which in the initial phases is related to the stimulation observed.

J. G. DavIS

\section{P. W. Wruson and E. D. Kullmann. A statistical enquiry into methods for esti-} mating numbers of Rhizobia. J. Bact. 22, i, 71-90, July 1931.

Various ways of estimating bacterial numbers were employed. Variability resulting from the use of only one plate in a series can be partly eliminated by using three or more plates, of which any one markedly abnormal may be rejected without prejudice to the results. The best results were secured by the use of the Petroff-Hausser counting chamber. Results are treated statistically. (Although Rhizobium is an organism requiring rather special conditions for growth, the methods used in this paper may be studied with profit by those interested in methods of estimating bacterial numbers in other species.)

A. T. R. MatTick

T. R. VeRnon. An improved type of moist chamber for studying fungal growth. Ann. Botany, 45, 733-7, October 1931.

About 3 drops of a 2 per cent. agar medium are added to a sterile slide at a temperature of $80-90^{\circ} \mathrm{C}$. When the medium is about to gel a sterile cover-slip is placed on it and gentle pressure used to flatten it. When the medium has set, the cover-slip is removed and the disc cut in half with a sterile knife or safety razor blade. One half is then pushed aside, one of the cut surfaces inoculated and the whole covered with a sterile cover-slip. The preparation is incubated in a moist atmosphere. The entire process of growth and sporulation may be studied, either with dry or immersion lens, in such preparations.

J. G. DAvIS

F. WREDE. Ueber das Prodigiosin, den roten Farbstoff des Bacillus prodigiosus. (Prodigiosin, the red pigment of B. prodigiosus.) Zts. f. Hyg. 111, 531, 1930. (Bull. Inst. Pasteur, 29, xiv-xxxi, 704, July 1931.)

Prodigiosin is insoluble in water, soluble in fat solvents and more intense than fuchsin in colour. It is, however, turned yellow by sunlight and by acids. The empirical formula is $\mathrm{C}_{20} \mathrm{H}_{25} \mathrm{~N}_{3} \mathrm{O}$. It forms well-defined salts, and is only reduced by hot sodium amalgam, but easily oxidised by permanganate.

J. G. DAVIS

B. Blankov and Z. Gringot. Unterschiede in der durch die Coli-Typhusgruppe hervorgerufenen Gärung unter aëroben und anaëroben Bedingungen. (Differences in fermentation caused by the coli-typhoid group under aerobic and anaerobic conditions.) Mikrobiol. Z. 9, 248-53, 1929.

The sugar-fermenting abilities of the coli-typhoid group under aerobic and anaerobic conditions have been tested by half covering growing slope cultures with vaseline oil. The results with 24 strains of coli were not uniform. The results with lactose, maltose, glucose and galactose media were the most consistent, the first two sugars only being fermented anaerobically and the last two equally well beneath and above the oil layer.

It is suggested that further development of this principle may lead to improved methods for species identification.

J. G. Davis

L. H. Stickland. The reduction of nitrates by Bact. coli. Biochem. J.25, v, 1543-54, 1931.

$B$. coli quantitatively reduces nitrates to nitrites. Toluene does not affect the oxidation of formate and lactate either by oxygen or by nitrate, but cyanide inhibits this oxidation completely. Carbon monoxide is without effect.

In the presence of both oxygen and nitrate, lactate is oxidised chiefly by oxygen, 
due to the "saturation concentrations" of the enzymes, hence a reduction of oxygen pressure leads to increased reduction of nitrate.

J. G. DAVIS

G. S. Wirson. The growth of Br. abortus (bovine type) in shake tubes. Brit. J. Exp.

Path. 12, iii, 152-65, June 1931.

Bovine strains of $\mathrm{Br}$. abortus when grown in agar shake cultures form a band about $2-5 \mathrm{~mm}$. below the surface. Evidence is given that growth does not occur above this zone because of the loss of $\mathrm{CO}_{2}$ into the air, or below because of the very low oxygen tension, both oxygen and $\mathrm{CO}_{2}$ being necessary for growth.

The double zone phenomenon observed by Bang and Stribolt is explained by the alkali formation of the upper band, which, forming carbonates from the $\mathrm{CO}_{2}$ present, removes the latter and so prevents growth for some little distance.

J. G. DAVIS

\section{DaIRy Bacteriology.}

MrNistry of Health. Memorandum on bovine tuberculosis in man with special reference to infection by milk. Reports on Public Health and Medical Subjects, No. 63. (J. State Med. 39, viii, 490-1, August 1931.)

The subject is dealt with under the following: the incidence of human tuberculosis in England and Wales; the proportion of cases attributable to bovine infection; the incidence of tuberculous disease in cattle with results of the tuberculin test, abattoir statistics, clinical cases detected by routine veterinary inspection and the proportion of cows suffering from tuberculosis; tuberculous milk, with a review of milk as a vehicle of infection, the proportion of cows yielding such milk and the proportion of milk so infected; the methods of controlling infection, at the source by eradication by slaughter, establishing tuberculosis-free herds, by immunisation with B.C.G., by routine examination of cattle and the bacteriological examination of milk, etc. The education of cow-keepers and the improved methods of cow-keeping are considered and the part played by the grading of milk in the campaign against tuberculosis. Pasteurisation is defined and the whole situation and subject briefly summarised.

H. E. Hasseltine and I. W. KNight. Outbreak of undulant fever traced to infected milk supply. Pub. Health Rep. 46, xxxix, 2291-300, September 25, 1931.

Six cases of undulant fever occurred in a town of 5387 population. All drank raw milk from the same dairy. The cases were diagnosed by means of agglutination tests which ranged from 1 in 500 to 1 in 1280. The agglutination test was also applied to each animal in the herd, and of 42 tested, 24 gave positive reactions in various titres. $B r$. melitensis var. abortus was isolated from two samples of the milk. The cultures were isolated by incubation in an atmosphere of increased carbonic tension and gave the reaction characteristic of $B r$. abortus (Bang) when grown on media containing thionin, methyl violet, and basic fuchsin according to the method described by Huddleson. No further cases occurred after pasteurisation of the milk from this dairy had been adopted, notwithstanding that for a time the milk of some of the animals that shed Brucella in their milk continued to be sold.

R. Stenhouse Winliams

O. Bang, I. Jundeli and H. Magnusson. Nouvelles recherches sur la vaccination des bovidés contre la tuberculose suivant le procédé de Calmette et Guérin. (New investigations on the vaccination of bovines by the method of Calmette and Guérin.) Ann. Inst. Pasteur, 47, iv, 386-407, October 1931.

Calves from one herd were inoculated subcutaneously with from $1 / 50$ to $1 / 100 \mathrm{mg}$. of a virulent bovine strain, some having previously been vaccinated by B.C.G. Of nine animals infected but not vaccinated, four died of generalised tuberculosis, two 
became obviously tuberculous and three apparently healthy calves were found on autopsy to have extensive lesions. Of thirteen animals vaccinated previously to inoculation, six failed to develop lesions visible to the naked eye, three developed only insignificant lesions, one died, one was killed in a state of advanced tuberculosis and two were found on autopsy to have serious lesions. Thus while 100 per cent. of the unvaccinated calves developed tuberculosis lesions, only 54 per cent. of those vaccinated with B.C.G. did so.

J. G. Davis

H. Alfonsus and O. CoRrell. Nachweis von thermophilen Bakterien mittels der Reduktaseprobe bei $63^{\circ} \mathrm{C}$. und ihre praktische Anwendung im Molkereibetrieb. (Detection of thermophilic bacteria by means of the reductase test at $63^{\circ} \mathrm{C}$. and its practical use in the dairy industry.) Hildesheim Molk-Ztg. 44, 1237-9, 1930. (Zbl.f. Bakt. II, 83, i-vii, 87, February 1931.)

To gain an insight into the relative thermophilic bacterial content of milk the methylene-blue reductase test at $63^{\circ} \mathrm{C}$. is a simple and certain method. Pasteurisation apparatus used for a long time caused a great increase in thermophiles, and at the same time a sweet taste in the milk. Milk from the larger farms contained fewer thermophiles than holder-pasteurised milk from factories or raw milk from small holdings.

RühmekoRF. Ueber die Bedeutung des Gesamtkeimgehaltes und des Colititers in der Milch. Der Coligehalt von Leipziger Milchsorten. (Importance of total germ content and coli titre in milk. Coli content of various types of Leipzig milk.) Milchw. Forsch. 11, vi, 600-14, April 1931.

This paper is an account of an investigation of the milk supply of Leipzig from the hygienic point of view. The total counts and coli figures are given for various types of milk. The lactose brom thymol blue trypaflavin agar of Klimmer was used for coli determinations in addition to the usual lactose broth media for detecting gas formation. The original concentration of 1 in 20,000 for the solid medium was found to permit the growth of micrococci, hence trypaflavin in a concentration of 1 in 10,000 was used. (Milchw. Forsch. 9, 236.)

The coli colonies were somewhat smaller for this reason but still gave the typical colony form and yellowish colour. Usually the solid and liquid media results were correlated. A few milks gave gas without corresponding growths on the solid media and only very rarely was a solid medium "positive result" not confirmed by the gas tubes.

[For the solid medium test 1/10 c.c. of the milk is spread over dried trypaflavin lactose brom thymol blue agar in a Petri dish. Coli-aerogenes species give yellowish colonies, the aerogenes bacteria forming larger, opaque and slimy colonies, of a brighter yellow, and the paratyphoid group bluish forms. Either trypaflavin or rivanol may be used since these do not affect the indicator.] J. G. Davis

J. M. Rosell. The bacteriology of chronic streptococcic mastitis. Cornell Vet. 21, iv, 317-33, October 1931.

K. D. DownHam. The examination of milk for the presence of tubercle bacilli-a comparison between the cell group method and a method for the concentration of tubercle bacilli in milk. Vet. Record, 11, xxix, 756-8, July 18, 1931.

The author states that in his experience the cell group method is more satisfactory than the concentration method of Douglas and Meanwell. The results of 31 samples of tuberculous milk are shown in which the first definite acid fast bacillus was found in a shorter time in 24 cases by the cell group method. 
It is suggested that in cases of mixed udder infection, which include tuberculous mastitis, the concentration method may be the better.

The technique of smear preparation for examination by both methods is described.

J. MoClemont

H. R. Curran. The germicidal action of raw millk upon an organism of the sweet curdling type. J. Dairy Sci. 14, iii, 276-82, May 1931.

The effect of a sweet curdling Gram positive sporulating rod upon different milks has been studied. Raw mixed Holstein milk coagulated before raw mixed Jersey milk, but this difference was removed by sterilising the milk. This phenomenon was observed over a period of several months. Coagulation was delayed from $3 \frac{7}{2}$ to 6 hours in the case of the Jersey milk. The bacterial population at clotting was from 10 to 40 millions.

$S$. lactis was but little affected by the bactericidal substance, and did not appreciably influence the growth of the sweet curdler. Both organisms multiplied faster in the heated than in the raw (non-germicidal) milk.

J. G. Davis

C. C. WALTS. The action of Penicillium roqueforti on butter. Arkansas Agr. Exp. Sta. Bull. 257, 51-2, 1930.

From this preliminary report of experiments in progress on the growth of various moulds and yeasts in butter and cream it appeared that Penicillium roqueforti actually grew in the butter when the moisture, salt and oxygen conditions were favourable. The butter acquired a mouldy flavour and an odour resembling Roquefort cheese.

E. R. Hiscox

B. W. Hammer and J. A. Nelson. Bacteriology of butter. II. A method for the microscopic examination of butter. Iowa Agr. Exp. Sta. Res. Bull. 137, February 1931.

The butter is melted and centrifuged in a separating funnel held in a special apparatus and the serum drawn off. $0.01 \mathrm{ml}$. is then spread over a given area of a slide as in the Breed method. The examination is then made according to the official methods. $10 \mathrm{ml}$. of butter give, on centrifuging for 1 min. at 1000 r.p.m., 1 to $1.4 \mathrm{ml}$. of serum according to the moisture content. Accordingly the serum count should be divided by from 11 to 7 to convert to the butter count. The percentage of bacteria left in the fat is about 0.1 per cent.

J. G. DAvis

B. W. Hammer and H. C. Olson. Bacteriology of butter. III. A method for studying the contamination of churns. Iowa Agr. Exp. Sta. Res. Bull. 141, June 1931.

$10 \mathrm{ml}$. of an agar medium is poured over a moistened area of the churn or other surface to be examined. After solidification the agar layer is removed and incubated in a Petri dish for 4 days at $21^{\circ} \mathrm{C}$. Good photographs are given showing the types of "plate" obtained with churns of different condition. Modifications are discussed, e.g. the determination of yeasts and moulds on surfaces. J. G. Davis

W. G. Savage, F. C. Minetr, et al. Discussion on milk-borne streptococcus epidemics.

Proc. Roy. Soc. Med. 24, xii, 1703-12, October 1931.

The literature of this subject was fully discussed and much new work reported. Reference was made to the recent Hove epidemic and its widespread nature in contrast to another, but smaller, outbreak in which contamination of the milk in transit was the probable cause (Wilkinson).

Savage, Minett and others agreed (i) that although streptococci were extremely common in milk the vast majority were of one or other of the common bovine types and harmless to man; (ii) that a number of epidemics of septic sore throat and scarlatina had been traced to actual infection of the cow with types not normally pro- 
pagated in the bovine udder but implanted from a human source; such streptococci had not infrequently been found unassociated with any human disease; (iii) that contamination of milk in transit by streptococci was not a common source of outbreaks; the magnitude of the outbreaks aud their continuous nature alone made this unlikely. Further, the growth of streptococci of human origin was inhibited in fresh cow's milk; (iv) that it had been shown that severe mastitis accompanied by the excretion of large numbers of organisms could be set up experimentally by means of a very small number of streptococci and that the condition often continued for weeks or months.

Minett stated that the streptococci of scarlatina and septic sore throat, being haemolytic, were not likely to be confused with non-haemolytic streptococci of bovine origin. Moreover, they were distinguished from the common haemolytic streptococci of bovines by their greater action on red cells, their inability to split hippurate to glycocoll and benzoic acid, their relatively low depression of the $p H$ of lactose broth and their high virulence for mice and rabbits.

Stableforth reported that human streptococci were sharply distinguished from bovine strains of all types by their antigenic characters as demonstrable by precipitation and agglutination with immune sera.

The last two speakers also reported the isolation of a number of strains from severe cases of bovine mastitis which were indistinguishable as a group from $S$. pyogenes of direct human origin but unassociated with any known disease in man.

A. W. Stablefforth

\section{CHEMISTRY (ORGANIC, INORGANIC AND PHYSICAL).}

\section{General.}

O. L. Osburn and C. H. Werkman. Determination of organic acids. V. Application of partition method to quantitative determination of acetic, propionic and butyric acids in mixture. Ind. Eng. Chem. (Anal. Ed.), 3, iii, 264-5, July 1931.

The determined normality of the acid mixture must lie between 0.08 and 0.12 . Equal volumes (25 c.c.) of the acid mixture are partitioned with two known volumes (30 and 60 c.c.) of isopropyl ether and the aqueous layers titrated. Percentage partition constants for these volumes having been worked out previously, three simultaneous equations are available from which the percentages of the three acids can be calculated. A nomogram for this purpose is included.

W. L. Davires

S. Ansbacher, R. E. Remington and F. B. Culp. Copper determination in organic matter. Ind. Eng. Chem. (Anal. Ed.), 3, iii, 314-7, July 1931.

A comparative study of the various micro-methods for the determination of copper in organic material is described. With the zanthate method the error is least when the amount of copper is $0 \cdot 1$ to $0.2 \mathrm{mg}$. while the Biazzo reagent is most reliable for 0.05 to $0.15 \mathrm{mg}$. and the carbamate for $0.05 \mathrm{mg}$. of copper. The chromotropic reagent is sensitive to $0.003 \mathrm{mg}$. and by colour comparison an amount of copper of this order can be determined within $0.0005 \mathrm{mg}$.

W. L. DavieS

G. M. MoIr. The use of the quinhydrone electrode. Analyst, 56, 664, 445-8, July 1931.

The use of the quinhydrone electrode for the determination of hydrogen-ion concentrations has the advantage of rapidity and that semisolid material can be worked on. A description is given of a simple assembly of boiling tubes adaptable for the rapid determination of the $p H$ of liquids given. The reference electrode consists of a solution $0.1 \mathrm{~N}$ with respect to both sodium acetate and acetic acid $(p \mathrm{H} 4 \cdot 626)$. This is coupled by a saturated $\mathrm{KCl}$ bridge to a tube containing saturated $\mathrm{KCl}$ which in 
turn is coupled to a tube containing the solution of unknown $p \mathrm{H}$ by a $\mathrm{KCl}$-agar bridge. About $0.1 \mathrm{~g}$. of quinhydrone is added to the electrode tubes (with immersed gold electrodes) and the E.M.F. of the cell determined by a potentiometer, the $p \mathrm{H}$ of the unknown liquid being calculated from the equation:

$$
p \mathrm{H}=2.03+E /(0.0577+0.0002(t-18)),
$$

where $E=$ E.M.F. and $t$ is the temperature $\left({ }^{\circ}\right.$ C.). Particulars are given for making, testing and cleaning the gold electrodes.

W. L. Davies

\section{J. G. Davis. A simple inexpensive quinhydrone cell for rapid work. Analyst, 56,} 664, 449-50, July 1931.

An apparatus is described for determining the $p \mathrm{H}$ of liquid or solid substances (e.g. cheese) without the aid of salt-agar bridges or glass taps. Each half cell consists of $\frac{1}{2}$ in. pyrex tubing drawn out to a point and bent in the form of an $\mathbf{S}$. The capillary tips dip in $3.5 \mathrm{~N} \mathrm{KCl}$. The reference electrode contains a solution of 9 parts $0.1 \mathrm{~N} \mathrm{KCl}$ and 1 part $0.1 \mathrm{~N} \mathrm{HCl}$. Solids are ground with quinhydrone and either packed into a short piece of tubing, one end dipping into a crucible containing $3.5 \mathrm{~N} \mathrm{KCl}$ while a gold electrode is inserted into the mush at the other end, or the mush is packed into a crucible and the tip of the reference electrode and a gold electrode inserted into it. Good results were obtained for well-buffered solids over a $p H$ range of from 3 to 7 .

W. L. Davies

\section{Dairy Chemistry.}

E. Lesné, R. Clément and P. Zizine. Sur la teneur en fer du lait de femme et du lait de certains mammifères (ânesse, chèvre, vache). (Iron content of human milk and of that of certain mammals, ass, goat, cow.) Le Lait, 11, 104, 355-8, April 1931.

The iron content was determined colorimetrically with alloxantin by the method of Zizine, using 500 c.c. of milk to avold the error due to multiplication when a micro-estimation is performed. The milks of the four species contained approximately the same concentration of iron, viz. slightly less than $1 \mathrm{mg}$. per litre. There seems to be no justification for blaming a relatively low iron content as the cause of anaemia in animals fed on goat's milk.

G. L. PesketT

\section{G. W. Monier-Williams. The nitrate test for the detection of added water in milk.} Analyst, 56, 663, 397-8, June 1931.

The test for nitrate in milk can be made more sensitive if diphenylbenzidine be substituted for diphenylamine which has been recommended by earlier writers. The same blue compound (a quinone-imonium salt of diphenylbenzidine) is formed in both cases but the oxidation of diphenylamine at the expense of some of the nitrate is avoided. With diphenylbenzidine a good gradation of colour is obtained with amounts of nitrate ranging from 0.1 to 1 part per million. Marqueyrol and H. Muraour's method of preparing the reagent is described in detail. J. Gondra

H. IlzHÖFER. Ueber den Nachweis stattgehabter Erhitzung der Milch. (Test for heated milk.) Archiv f. Hyg. 105, vi, 319-21, April 1931.

A modified peroxidase test for heated milk is described. One part of a 1 per cent. solution of orthotolidin (Merk) in 10 per cent. acetic acid is added to five parts of 1 per cent. hydrogen peroxide. 0.5 c.c. of this mixture is then added to 5 c.c. of the milk serum (lead acetate method). The following colour reactions are claimed: raw milk-deep blue; holder-pasteurised milk-bright blue-green; milk held at $75^{\circ} \mathrm{C}$. for $\frac{1}{2}$ hour or $85^{\circ} \mathrm{C}$. for 1-2 min.- - no colour.

J. G. Davis 
R. Sasaki and E. Hiratsuka. Phosphatides of cow's milk. Proc. Imp. Acad. Tokyo, 7, 99-100, 1931. (Brit. Chem. Abst. A, p. 862, July 1931.)

Methods are outlined for the isolation and separation of the phosphatides of dried milk. The fatty acid constituents are saturated, and the phosphatide content of milk containing 3.5 per cent. of fat is: myristolaurolecithin 0.003 per cent., and palmitolaurocephalin 0.007 per cent.

A. Schneck and C. Schlenz. Ueber den Tyndalleffekt der Milch. (The Tyndall effect in milk.) Milchw. Forsch. 11, iv-v, 344-67, March 1931.

Experiments are described in the study of the turbidity of milk by the breaking up and absorption of light rays (Tyndall effect) by the disperse particles. The constituents mainly responsible for the effect are the fat in whole milk, the casein in skim milk, and the soluble proteins in the variously prepared sera. Significant differences were found for the effect of sera of pasteurised milk as against the sera of the same samples of milk in a raw state, but the sera of different samples of holderpasteurised milk did not show significant variations. The application of this method to differentiate between raw and pasteurised milk needs further investigation.

W. L. DAVTES

\section{A. Allen, Observations on some alcohol-soluble proteins from milk products.}

Biochem. J. 25, iv, 1045-50, 1931.

Three proteins soluble in 80 per cent. ethyl alcohol, have been separated from Cheddar cheese (two) and from a peptic digest of casein (B.D.H. "Light White Casein"). The methods of separation and analysis are described. The proteins differed considerably in composition from casein and showed appreciable differences between themselves. The nitrogen content was lower (14.95-15.21 per cent.), but their main characteristic was a low phosphorus content $(0.03-0.20$ as against 0.82 per cent. in casein). The view that they are decomposition products of casein is discussed.

W. L. Davies

M. Polonovski and A. Lespagnol. Le dosage des sucres du lait de femme par l'iode. (Estimation of sugars of human milk by iodine.) C.R. Soc. Biol. 107, xvii, 301-3, June 3, 1931.

The authors claim the presence of three different sugars in human milk, lactose, gynolactose and an unnamed third. The three differ in chemical and physical properties. Gynolactose can be estimated in the presence of lactose by taking advantage of its low reducing power against alkaline iodine solution ( $10 \mathrm{~g}$. equivalent in reducing power to $3.4 \mathrm{~g}$. of lactose). In the copper reduction (Bertrand) method also $10 \mathrm{~g}$. is equivalent to $5 \mathrm{~g}$. lactose. Differences in the rotatory power of human milk sera as against values calculated from analytical data can only be explained by the occurrence of a third sugar having the same reducing power as lactose but more dextrorotatory. Gynolactose accounts for 10-13 per cent. of the total sugars in human milk.

W. L. Davies

Many metals are soluble in milk. Wisconsin Agr. Exp. Sta. Bull. 420, 71-2, February 1931.

Acidity of milk increases the solubility of zinc, tin, solder and aluminium and decreases the solubility of copper and its alloys and nickel. The important factor in the solution of the latter group being dissolved oxygen. Iron and aluminium are protected by dissolved oxygen. Increase of temperature increases the amount of all metals going into solution, reaching a maximum at about $160^{\circ} \mathrm{F}$., irrespective of the acidity of the milk. Aluminium resists corrosion when no other metal is present, but the galvanic effects due to another metal being in contact with the same milk, 
greatly increase the solubility. Copper alloys are more soluble than aluminium and the various stainless steels and should be used only in conditions where they show minimum solubility. Nickel is rapidly dissolved but has little effect on milk. Tin plating is not resistant to the corrosive effect of cleaning compounds and solder coated surfaces are appreciably soluble in milk. Chromium and nickel chromium steels resisted corrosion very well and resisted the attack of alkaline washing compounds.

W. L. Davies

Popp. The metals in the milk industry. Land. Vers.-Sta.111, 271-91, 1931. (Chem. Abst. 25, xii, 3093, June 20, 1931.)

The order of the decreasing resistance to corrosion of the five pure metals which were used is $\mathrm{Ni}, \mathrm{Cu}, \mathrm{Fe}, \mathrm{Zn}$ and $\mathrm{Al}$. The best alloy is a mixture of $\mathrm{Fe}, \mathrm{Ni}$ and $\mathrm{Cu}$.

H. T. Gebhardt and H. H. Sommer. The solubility of metals in milk. I. The solubility of copper under various conditions. J. Dairy Sci. 14, v, 416-46, September 1931.

The solubility of copper in milk has been studied under careful experimental conditions. Higher acidity of milk decreased copper solubility. Oxygen and air increased and carbon dioxide decreased the solubility. Irrespective of length of time of exposure, maximum copper solubility took place at $70^{\circ} \mathrm{C}$. Preheating milk decreased its dissolving effect. The rate of solution was found to be related to the oxidation-reduction potential. The interrelation of the various effects of the factors influencing the rate of copper solubility is discussed from the oxidation-reduction potential viewpoint.

W. L. DAvIES

\section{J. Csiszar. Dissolving effect of sour milk on lead plates. Kiserlet. Közlenenyek, 32 ,} 495-501, 1929. (Chem. Abst. 25, xii, 3093, June 20, 1931.)

The solution of lead from lead plates depends on the acidity of the milk, the time of exposure and the quality of the lead surface. Exposure of smooth bright lead plates for 36 hours to milk of 0.55 per cent. acidity caused no solution, but similar plates with a rough surface lost up to $0.24 \mathrm{mg}$. per square decimetre. Plates with smooth oxidised surfaces lost up to $0.14 \mathrm{mg}$. per $\mathrm{dm}^{2}$ but rough oxidised plates in milk of 0.53 per cent. acidity lost 0.52 per $\mathrm{dm}^{2}$ Increase in acidity increased the quantity of lead dissolved to a maximum, after which a decrease was observed.

W. L. Davies

G. Bertrand and P. Serbescu. Sur la toxicité de l'aluminium comparée à celle du fer, du nickel et d'autres métaux. (The toxicity of aluminium compared with that of iron, nickel and other metals.) Ann. Inst. Past. 47, iv, 451-7, October 1931.

The toxicities of some metals were compared by injecting $100 \mathrm{mg}$. per $\mathrm{kg}$. live weight (dissolved as salts in distilled water) subcutaneously into the abdomen of the guinea-pig and the rabbit and noting the time of survival. The toxicities were found to be as follows (hours of survival) $\mathrm{Cu} 0.52$; $\mathrm{Ni} \mathrm{1.00;} \mathrm{Cd} \mathrm{1.19;} \mathrm{Co} \mathrm{2.17;} \mathrm{Zn} \mathrm{3.01;}$ $\mathrm{Mn} 7 \cdot 14 ; \mathrm{Fe}$ (ferric) 7.51 ; Al 8.34 and $\mathrm{Fe}$ (ferrous) 8.44 . The author concludes that no danger is incurred by the use of utensils of aluminium for containing food. Copper and nickel should be avoided.

J. G. DAVIS

G. Testoni and W. Crusa. Determination of biacetyl in butter. Ann. Chim. applicata, 21, 147-50, 1931. (Chem. Abst. 25, xii, 3094, June 20, 1931.)

As a possible method for identifying pure butter, a method has been developed for determining the biacetyl in butter. The biacetyl is separated from butter by steam distillation and treated in boiling solution with $\mathrm{NH}_{2} \mathrm{OH}$, and a few drops of 0.1 per cent. $\mathrm{NiSO}_{4}$ solution and $\mathrm{NH}_{4} \mathrm{OH}$ (concd.). A red precipitate of nickel dimethyl- 
gloxime is formed. The precipitate may be weighed or estimated colorimetrically. Melted and pasteurised butter as well as margarines do not contain any biacetyl, whereas fresh butter contains about 0.0005 per cent. Its presence becomes a measure of the freshness of the sample of butter.

\section{G. D. Elsdon, R. J. TAYLor and P. Smith. The Reichert, Polenske and Kirschner values of rancid butters and margarines. Analyst, 56, 665, 515-18, August 1931.}

The Reichert value of butter is not appreciably changed when butter samples have been exposed for several weeks to the effects of light and air, although the free fatty acids might show considerable increase. Exposure to light causes a marked increase in the Polenske value. But with margarine fats, developing rancidity under similar conditions, a rise in the Reichert value is observed. The Kirschner value also increases whilst the Polenske value shows a variable change. If the butterfat present in a margarine is determined by the Reichert-Polenske + Kurschner process, care must be taken that the margarine is not rancid and that the values obtained for rancid mixtures be specially interpreted.

W. L. Davies

M. OTrE. Der Wassergehalt der Butter. I. Eine Methode der Wassergehaltsbestimmung für Butter mit hohem Wassergehalt. II. Der Wassergehalt roher, ungekneteter Butter. III. Der Wassergehalt gekneteter Butter. IV. Ueber die Adhäsion zwischen Butterfett und Wasser resp. Butterfett und Salzlake unter verschiedenen Bedingungen. V. Ueber die Haltbarkeit der Butter, unter besonderer Berücksichtigung der Wasserverhältnisse in der Butter. VI. Untersuchungen zur Luftgehaltsbestimmung. (Water content of butter. I. Method for estimating water content of butter with high water content. II. Water content of raw unworked butter. III. Water content of worked butter. IV. Adhesion of butterfat and water and butterfat and salt brine under various conditions. V. Keeping quality of butter, with special reference to the proportion of water in butter. VI. Determination of air content.) Milchw. Forsch. 11, vi, 537-40; 541-50; 551-71; 572-6; 578-82; 583-9; April 1931.

I. In determining the moisture content of unworked butter the sampling and preparation of the sample are important. It is advisable to emulsify thoroughly, preferably adding an emulsifying agent (in this case, Palsgard Emulsionsol). Samples of about $2 \mathrm{ml}$. can then be pipetted out and the moisture determined, by drying in a vacuum oven at $100^{\circ} \mathrm{C}$. (Boysen method).

II. The moisture content of unworked washed butter depends primarily on the total area of the fat globules and on the temperature conditions which determine the adsorption of water on the fat. The influence of churning temperature is counteracted by washing. If the cream acidity is sufficiently high to cause protein coagulation the increase in surface thereby causes an increase in moisture content. The previous treatment of the cream has little effect, but washing with salt water diminishes the moisture content, depending on the salt content of the water.

III. The working of butter decreases the moisture content to a minimum value, after reaching which, further working causes a slight increase of moisture. This "minimum moisture content" is lowered by long cooling of the cream, but cream acidity has very little effect. Increasing the speed of the butter-worker increases the value, but pasteurisation of the cream, length of churning time and speed of the churn do not affect the value beyond the usual limits of variation. The degree of churning of the cream in determining the grain of the butter has an important effect on the moisture content, over-churning causing a reduction.

IV. The conditions in the churning of butter which govern the adhering of moisture to butterfat are: the temperature of the wash water, the type of fat, summer 
butterfat causing more moisture to adhere to it than winter fat; the method of cooling cream, in that sudden chilling of cream to a low temperature gives a butter of higher moisture content than cream kept at a moderately low temperature for a considerable length of time; on the quantity of dissolved salt in the brine, in that less adhering of water to fat occurs in brine than in water.

V. Storage of butter at $-18^{\circ} \mathrm{C}$. preserved well the texture of butter. There was no difference in the texture of spring and summer butter, of unsalted, slightly or heavily salted butter under such storage conditions. Variations in moisture content in butter did not influence texture during storage and there was no effect due to high air content in butter.

VI. An accurate method is described for determining the air content of butter depending on the fact that air is the only component of butter liable to change in volume under pressure. The air content is of no practical importance in butter.

W. L. Davtes

\section{H. Lampitt and N. D. Sylvester. Action of air and light, particularly on butter.} Chimie et industrie, Spec. No., pp. 642-7, March 1931. (Chem. Abst. 25, xiv, 3737, July 20, 1931.)

It is considered that the taste of rancid fat is the resultant of two different tastes, one due to structural changes in the glycerol portion of the molecule, and the other caused by changes in the constituents producing the original taste, and it is thought possible that one factor can come into play independently of the other. Lampitt and Sylvester wish to restrict the term "rancidity" to include only the phenomena resulting from changes in the glycerol radical of a fat or oil, and to introduce the expression "tallow taste" to designate the taste due to the changes taking place in the constituents producing the original taste. The Kreiss test (which does not lend itself to a quantitative study of the changes occurring in fats) does not give a true indication of the rancidity (considered from an organoleptic standpoint). The Issoglio test is useful, not as an indication of rancidity or tallow taste but as a method of measuring the initial changes taking place when a fat deteriorates under the effects of air and of ultra-violet rays, and it can give a quantitative measure of these changes before the stage of positive Kreiss tests has been reached. Experimental results obtained by irradiation (in the presence and absence of air) of $\mathrm{Et}_{2} \mathrm{O}$ and petroleum ether solutions of butterfat support these views.

\section{G. Genin. Constitution physico-chimique de la poudre de lait desséché. Les matières}

grasses de la poudre de lait desséché par pulvérisation. (Physico-chemical constitution of dried milk powder. The fat of spray-dried milk powder.) Le Lait, 11, 106, 589-97, June 1931.

In a review of the subject the author points out that comparatively little work has been done on the physico-chemical properties of milk powder and that probably the contradictory results obtained by different workers as to the effects of storage on keeping quality and solubility are due to the fact that they have compared powders with very different physical structures.

Since it is difficult to bring colouring matters and solvents into contact with the fat contained in milk powder, it is assumed that the fat is protected by a film of protein. Lampitt and Bushill have therefore defined "free fat" as that portion of the fat which can be extracted by solvents such as carbon disulphide under standard conditions.

Figures are given which show that for eight samples of "Milkal" spray-dried milk the percentage of total fat which is in the free condition varies from $3 \cdot 3$ to $14 \cdot 2$, while for five samples of roller-dried milk the percentage varies from 91.6 to $95 \cdot 8$. The

Jour. of Dairy Research III 
author concludes that such a considerable difference between the two types is due to the fact that, in spray-drying, the milk is actually dried in the form of particles whereas, in roller-drying, it is dried as a continuous film and pulverised afterwards. The size of the particles is a factor influencing the free fat content of spray-dried milk; thus crushing results in an increase because of the greater total surface.

In spray-dried milk there is a critical moisture content at which the fat becomes free and is extracted by solvents. For powder with a fat content of $27-8$ per cent., this critical moisture content is $8 \cdot 6-9 \cdot 2$ per cent.

L. A. ALLEN

\section{L. HINTON and T. MACARA. The determination of laevulose in sweetened condensed milk. Analyst, 56, 662, 286-92, May 1931.}

Laevulose may be present in sweetened condensed milk either as a product of the breaking down of sucrose or from invert sugar added. The method of its estimation depends on its copper reduction capacity after the preliminary oxidation of aldose sugars (glucose and lactose) by alkaline iodine. Excess of iodine used for oxidation of aldose sugars is quantitatively removed with sodium sulphite solution, while the copper reduction by laevulose is carried out by using the citrate-carbonate reagent of Luff (similar to Benedict's quantitative copper reagent). Certain standard technique is essential and factors for calculation are supplied for which the original paper should be consulted.

W. L. Davies

\section{BIOCHEMISTRY.}

J. WADDELL and H. STEEnBock. Vitamin $\mathbf{E}$ in iron-treated dry rations. J. Nutrition, 4, i, 79-93, May 1931.

A mixed stock ration (Waddell and Steenbock, J. Biol. Chem. 80, 431, 1928), treated with an ether solution of ferric chloride (1 part of iron salt to 99 parts of the diet) produces sterility in male rats reared on it. It also induces 100 per cent. sterility in female rats. There is no first litter fertility. The iron treatment brings about the formation of a substance which actively opposes vitamin $E$. It can be extracted from the iron treated ration with ether. It may be an anti-vitamin or possibly possess pro-oxygenic properties favouring the destruction of vitamin $\mathrm{E}$. S.K. KoN

\section{L. Hussemann and R. A. Hetler. The vitamin B and G requirements of lactation.}

J. Nutrition, 4, i, 127-40, May 1931.

Either vitamin $B$ or $G$ in quantities above and added to the maintenance level of the vitamin $B$ complex are required for lactation. It is suggested that vitamin $G$ is the most important for successful lactation.

(Vitamins $B$ and $G$ are called $B_{1}$ and $B_{2}$ in the terminology adopted in England.)

S. K. KoN

G. C. SuppleE and O. D. Dow. The effect of ultra-violet irradiation on the antiscorbutic vitamin of liquid and dry milk. Amer. J. Dis. Child. 41, 1353-62, 1931. (Bull. Hyg. 6, x, 769, October 1931.)

Irradiation of dry milk caused no destruction of the vitamin $\mathrm{C}$ contained therein, irradiation of liquid milk caused slight destruction of vitamin $\mathrm{C}$, but the amount remaining in the milk was not reduced below the level frequently found in untreated mill. Irradiation in both cases was of sufficient duration and intensity to impart marked antirachitic properties to the milk.

R. G. BоOTH

K. Schlegr. The prophylaxis of rickets by means of irradiated milk. J. State Med. $39, \mathrm{x}, 607-9$, October 1931.

Milk irradiated by the Scholl system will cure advanced rickets in four to eight weeks when fed (to children) at the rate of half a litre daily. The milk is unaltered in 
flavour or smell and is readily taken. Prophylaxis is accomplished by $300-400$ c.c. of the milk daily. Half a litre a day drunk by the nursing mothers confers absolute freedom from rickets on her child.

R. G. BOOTH

B. H. Thomas and F. L. MacLeod. Increasing the vitamin D potency of cow's milk by the daily feeding of irradiated yeast or irradiated ergosterol. Science, 73, 618, 1931. (Amer. J. Publ. Health, 21, viii, 951, August 1931.)

In this experiment varying quantities of vitamin $D$ as irradiated yeast and irradiated ergosterol were fed to dairy cattle, and the effect of this supplementary feeding on the vitamin $D$ content of the butterfat was investigated.

The cows were 21 in number, divided into 7 groups of three each, and were fed on a basal ration of alfalfa meal, corn silage, beet pulp and grain mixture. The preexperimental period lasted 3 months and the experimental supplements were fed for a period of 4 weeks.

The results obtained are summarised in the following table where the vitamin D potency of the butterfat of the control group of cows is taken to be one arbitrary unit, the potency in rat units per gram not being stated:

Vitamin D, No. of Vitamin D, rat units of supple- potency of

\begin{tabular}{|c|c|c|c|}
\hline Group & Supplement & ment given per drem & butterfat \\
\hline I, Control & - & - & 1 \\
\hline II & Irradiated yeast & 10,000 & 2 \\
\hline III & , & 30,000 & 8 \\
\hline IV & " & 60,000 & 16 \\
\hline$\nabla$ & Irradiated ergosterol in corn oil & 15,000 & 2 \\
\hline VI & " & 45,000 & 4 \\
\hline VII & ", & 135,000 & 16 \\
\hline
\end{tabular}

The fact that the vitamin $D$ potency of milk can be easily and cheaply increased to this extent is important, especially in so far as it increases the assimilation of the calcium and phosphorus of the milk.

R. G. Воотн

E. G. BRown. Report of Committee on Milk, Conference of State and Provincial Health Authorities of North America. Publ. Health Rep. 46, xxv, 1455-60, June $19,1931$.

The Committee recommends the acceptance and approval by the Conference of State and Provincial Health Authorities of the entire Report of the Committee on Milk Production and Control, of the White House Conference on Child Health and Protection (cf. abst. J. Dairy Res. 3, i, 175). The Committee advocate that milk consumption should be increased rather than reduced, even when it becomes necessary to readjust the family budget. Two articles, one by Scott and Erf (cf. Jersey Bulletin, February 11, 1931), the other by Mattick and Golding (The Lancet, p. 662, March 21, 1931), postulating a higher nutritional value for raw milk as compared with pasteurised milk, are discussed, and the experimental results are considered to be inconclusive and to afford no proof that raw milk possesses a dietary superiority over pasteurised milk.

Four other articles expressing the view that the nutritional value of milk is not impaired in the course of pasteurisation are cited. The committee urges the (U.S.) Public Health Service to undertake a study to determine the present experience with reference to the feeding of infants with raw and pasteurised milk.

(One of the four articles cited by the committee- the Lanarkshire Report-has recently been subjected to statistical analysis by Bartlett and Fisher, and Bartlett (Nature, No. 3207, 591, April 18, 1931 and J. Min. Agric. 38, i, 60-4, April 1931), and the results are believed by these authors to be in favour of raw milk.) 
J. WADDELL with the co-operation of E. vAN DoNK. Male sterility on milk diets. J. Nutrition, 4, i, 67-77, May 1931.

Total sterility in male rats has been observed on a diet of cow's whole milk supplemented with small amounts of iron and copper salts. This sterility is characterised by the complete disappearance of the germinal epithelium, great loss in amount of testicular tissue, and pronounced oedema. The view is expressed that this sterility is not due to lack of vitamin $\mathrm{E}$. The injury to the testis is less marked in animals receiving a diet of whole milk and copper only and is apparently intensified by some action of the iron salt (ferric chloride).

S. K. KoN

\section{J. WADDell, H. Steenbock and E. B. HaRT. Growth and reproduction on milk diets.}

J. Nutrition, 4, i, 53-65, May 1931.

On a diet of whole milk and copper a chronic anaemia ascribed to the low iron intake was observed. Growth and reproduction were below normal. Many of the young born were not nursed, and those that were suckled grew more slowly than young from the stock colony, being from 10 to $12 \mathrm{~g}$. underweight at weaning. On a diet of whole milk, iron and copper, no marked anaemia was observed (haemoglobin values $12 \mathrm{~g}$. per cent.) but growth and reproduction were still subnormal. The rearing of young was poor, due to poor mammary secretion. It is suggested that subnormal growth may be due to a low intake of calories in the liquid diet. No specific evidence of low vitamin B was observed. By means of daily vaginal smears late sexual maturity and very poor ovulation were detected in the females. Some of them never mated. Preliminary experiments indicate that the addition of small amounts of either manganese or iodine, or both, greatly improves the ovulation rhythm in females on the milk, copper, and iron diet. No evidence of lack of vitamin $E$ was noted in females on these milk diets.

S. K. KoN

E. W. Schwartze, F. J. Murphy and G. J. Cox. The effect of pasteurisation upon the vitamin $\mathbf{C}$ content of milk in the presence of certain metals. J. Nutrition, 4 , ii, 211-25, July 1931.

Certified milk (U.S.) about 12 hours old was pasteurised in a specially constructed laboratory apparatus in three pasteurisers constructed in aluminium, tinned copper and naked copper respectively. After a preliminary preheating period of about $10 \mathrm{~min}$. the milk was kept for $30 \mathrm{~min}$. at a temperature ranging from 58.5 to $60.5^{\circ} \mathrm{C}$. It was then fed to guinea-pigs receiving a scurvy-producing diet. The experiment took place between the middle of May and the middle of September. The results indicate a destruction of $20-40$ per cent. vitamin $\mathrm{C}$ in the aluminium pasteuriser, a slightly higher loss in the tinned copper one and at least $80^{\circ}$ per cent. destruction when naked copper was used. Aluminium is recommended as a satisfactory material for the construction of dairy equipment.

S. K. KoN

S. V. Telfer. Mineral metabolism in infancy. III. The substitution of cow's milk for human milk in infant feeding. Glasgow Med. J. 114, 265-84, 1930.

The diet of five infants (aged 7 to 11 months) was changed from human to cow's milk. The change resulted in

(i) Reduced mineral retention as a whole (percentage of the intake);

(ii) Reduced retention of iron;

(iii) Increased retention of bone-forming elements; and

(iv) Increased faecal output as regards bulk and mineral and fat content.

These results are explained on the basis of the exceedingly large mineral content of cow's milk, except in iron, and the fact that effective mineral absorption depends 
on the maintenance of the elements in soluble form by the acid agency of the upper part of the alimentary tract.

In early infancy the acidity of the tract is very low, and a high degree of absorption can be attained with human milk on account of its low mineral content. The use of cow's milk is inadmissible as the large excess of minerals results in formation and excretion of large amounts of insoluble soaps which impair fat absorption and mineral absorption as a whole. The large excess of bone-forming elements in cow's milk allows greater retention of these, but the percentage retention of the intake of these and all elements is reduced. Thus in the case of iron, the concentration of which is no higher in cow's than in human milk, the retention is diminished to dangerously low levels.

From the first year onwards there is risk of mineral deficiency if breast feeding be continued. Cow's milk, on the other hand, is well adapted to provide for the increased mineral requirements, but needs supplementing with iron. The value of cow's milk in the nutrition of school children is discussed briefly.

G. L. PesketT

\section{W. B. Nevens and D. D. Shaw. Effect of different plant processes (e.g. pasteurisa- tion, condensing, drying) on the nutritive value of milk. Illinois Agr. Exp. Sta. Ann. Rep. 1929/30, pp. 127-33.}

The object of these experiments was to find out if the treatment of milk by the specified processes would add enough copper or iron to affect its nutritive value.

The failure of rats to become anaemic on a diet of milk is attributed to the use of iron cages and to other metallic contamination. When filter paper was used in glass jars this also supplied iron. When rats were kept in cages made only of wood and glass with glass rods for flooring they developed anaemia. Restricted intake of milk caused the anaemia to develop more slowly.

J. GoLding

K. RIED. Untersuchungen über den Katalasegehalt der Kuhmilch. (Investigations on the catalase content of cow's milk.) Milchw. Forsch. 11, vi, 590-9, April 1931.

Determination of the catalase content of milk has been suggested as a means of diagnosing udder disease in the early stages. The author found that even aseptically drawn milk gave a positive catalase reaction. Various factors influenced the catalase content, e.g. first-drawn milk usually contained less than the last-drawn; the catalase content decreased during the first 8 days after the change from dry fodder to green stuff; and vice versa, the milk of pregnant cows showed a high catalase value during the last weeks before calving. Further, the catalase content of the milk of sick cows may be either high or low. Its determination will therefore be of little value for diagnostic purposes.

E. R. Hiscox

\section{K. A. Forster. Vitamingehalt der Sauermilchpräparate Yoghurt, Kefir und Saya.} (The vitamin content of the sour milk products, yoghurt, kefir and saya.) Biochem. Z. 236, iv-vi, 276-97, 1931.

Yoghurt is richer in vitamins $A$ and $D$ but contains less vitamin $B$ and $C$ than an equal weight of milk used for its preparation. The increase of the fat-soluble vitamins is only apparent, caused by a concentration of milk in the course of the manufacture of yoghurt. Kefir contains less vitamins $A, C$ and $D$ than the original milk. There is no significant difference in the vitamin $B$ content. Saya is twice as rich in vitamin $A$ as the original milk and contains $1 / 3$ more of vitamin $C$. Vitamins $B$ and $D$ remain unchanged. It is suggested that vitamins $\mathrm{A}$ and $\mathrm{C}$ are actually synthesised by bacteria in the course of fermentation. 
M. Lundborg. Zur Kenntnis des A-Vitamins im Butterfat. (The study of vitamin A in butterfat.) Biochem. Z. 235, i-iii, 1-13, May 30, 1931.

Higher values are obtained for the carotin content of butterfat when they are derived from the antimony trichloride reaction than when the carotin is estimated by direct colorimetric comparison of solutions of butterfat in petroleum ether with solutions comparing known amounts of pure carotin. The difference is due to the presence in butterfat of a colourless carotenoid substance- "Carotenoid X" - giving the antimony trichloride reaction and probably identical with vitamin A. S. K. KoN

B. G. E. Morgan and K. H. Coward. Estimation of vitamin A in butter. Lancet, No. 5640, 758-9, October 3, 1931.

The method described by Coward, Key, Dyer and Morgan (Biochem. J. 24, 1952, 1930, and 25, 551, 1931) and by Coward, Dyer, Morton and Gaddum (Biochem. J. 25, 1102,1931 ), for the estimation of vitamin A in cod-liver oils is shown to give consistent results also in the estimation of vitamin $A$ in butter and margarine.

S. K. KoN

H. Steenbock and A. M. WIRICK. Fat-soluble vitamins. XXXII. The determination of vitamin $A$ and its stability in butterfat to ultra-violet radiations. J. Dairy Sci. 14, iii, 229-49, May 1931.

Vitamin A was determined by the method of Steenbock and Coward (J. Biol. Chem. 72, 765, 1927), and it was found that it is developed by ultra-violet treatment even when the irradiation was carried out in an atmosphere of carbon dioxide, nitrogen or hydrogen, though the presence of these gases apparently retarded somewhat the destruction. This was found to be proportional to the time of exposure and inversely proportional to the thickness of the layer of butter exposed to ultra-violet irradiation. The irradiation necessary to secure maximum antirachitic activation of the butter was found to cause some destruction of vitamin A. Butterfat antirachitically activated was found to have retained most of its vitamin $A$ even after storage for seven months at room temperature.

S. K. KON

R. W. J J of fat-soluble vitamins. I. Studies with the vitamin $\mathbf{A}$ of butterfat. J. Nutrition, 4, ii, 171-84, July 1931.

The author was able to confirm the findings of Dutcher, Ely and Honeywell (Proc. Soc. Exp. Biol. and Med. 24, 953, 1927), that mineral oil causes a considerable loss of vitamin A in butterfat when mixed with the latter prior to ingestion, as measured on the rat. However, the administration of the mineral oil separately from the butterfat under conditions approximating those customary in human practice, results in only a very slight loss of vitamin A to the animal organism. S. K. KoN

A. Scheunert and E. W Agner. Ueber das Verhaiten des Vitamin-A-Gehaltes der

Butter bei verschiedener Erhitzungsweise. (The behaviour of the Vitamin A content of butter when heated in different ways.) Biochem. Z. 236, i-iii, 29-34, June 25, 1931.

No perceptible decrease in the vitamin A content of butter could be detected by the rat growth method after it had been used in the customary way for baking, roasting or browning. A marked loss of activity is caused by heating the butter for $\frac{1}{2} \mathrm{l} \mathrm{hr}$. in open pans at a temperature of $160-200^{\circ} \mathrm{C}$.

S. K. KON 


\section{PHYSIOLOGY.}

C. M. McCAY and L. A. MAYNARD. The interrelationship between the dietary fat and the phosphorus distribution in the blood of lactating cows. J. Biol. Chem. 92, ii, 273-80, July 1931.

Cows were fed for 5-week periods at three levels of fat intake, approximately 1, 3 and 7 per cent. The caloric intake was equalised by substitution of starch for the fat that was removed. Milk and fat yields were lower during the periods of lowered fat intake, as were the phospholipids and total phosphorus of the blood plasma, but not of the erythrocytes. It appears that the body cannot synthesise sufficient fat to permit the milk secretion that can occur when larger quantities of fat are given in the ration, though it should be noted that the change in the blood was gradual after changing the fat intake.

G. L. Peskett

A. Leroy and J. MarcQ. Le taux butyreux sanguin des reproducteurs bovins et ses rapports éventuels avec la valeur d'élevage (suite). (The butyric blood number of breeding cattle and its eventual bearing on the value of breeding (contd.).) Le Lait, 11, 103, 234-44, March 1931; 104, 259-69, April 1931.

In continuation of previous work it was found that the concentration of fatty acids of the blood show changes similar to the fat yield during the course of a complete lactation, falling to a minimum in the second or third month and then rising. Variations were also noted in relation to age and sex. With some exceptions (notably Jersey cows) the percentage of butterfat in the milk corresponded to the concentration of fatty acids in the blood $(r=+0.558 \pm 0.08)$, and to the concentration of total lipoids in the blood $(r=+0.601 \pm 0.08)$. In the case of a number of animals, all the progeny of the same sire, it was claimed that the fatty acids concentration in the blood placed them in the same order as the mean butter fat percentage of their respective dam's milk.

(The number of observations made, is, as the authors admit, almost too small to justify statistical analysis. From the physiological point of view it is doubtful whether any significance can be attached to the correlation which was found between the average butterfat percentage of one or more complete lactations and the average blood fatty acid percentage of one or two random samples.)

The last paper of the series records the experimental data of the individual cows that were studied.

G. L. Peskett

L. B. Winter. The metabolism of lactose. I. The occurrence of lactose in urine. J. Physiol. 71, iv, 341-55, April 1931.

This paper opens with a good discussion of previous work on the metabolism of lactose. In it are recorded 29 cases (human) of whom 16 showed lactosuria in the first few days of lactation though their urine had been sugar-free on the day after parturition.

Administration of $50 \mathrm{~g}$. of lactose by mouth causes very little to appear in the urine unchanged; its first effect is appearance of glucose or, galactose or both. On the other hand, injection of lactose into rabbits causes excretion of it in the urinein some cases in amounts greater than that injected.

G. L. Pesketr

J. Allardyce, R. H. Fleming, F. L. Fowler and R. H. Clark. Blood normals for cattle; some pathological values. Canadian J. Res. 3, ii, 120-4, August 1930.

This paper records analytical results for ten constituents of the blood from twentytwo normal cows. No significant variations were apparent except a marked effect of diet on the cholesterol content of blood. In nine animals suffering from various diseases the only notable variations occurred in a case of pyelonephritis, in which the conditions of the renal system might readily account for them.

G. L. PesketT 
H. S. Mrtchell and L. MrLleer. The effect of age, pregnancy and lactation on the haemoglobin of the albino rat. Amer. J. Physiol. 98, ii, 311-17, September 1931.

The haemoglobin content of the blood of young rats receiving a stock colony diet increased from 8.9 to $15.6 \mathrm{~g}$. per 100 c.c. during the period from 23 to 50 days of age. The average for adult rats ( 57 to 578 days of age) was $16 \cdot 2$ g. per 100 c.c. No significant difference was found between the sexes in this respect. The development of an anaemia, preceding parturition and progressing for three days following with a - subsequent spontaneous recovery has been observed in at least 92 per cent. of 145 pregnancies studied. (The maximal drop was to about $13.0 \mathrm{~g}$. of haemoglobin per 100 c.c. of blood.) Neither the addition to the diet of a mineral mixture containing iron, copper and manganese sulphates nor the inclusion of 0.59 daily of a yeast extract rich in vitamins $B_{1}$ and $B_{2}$ exerted any apparent influence in preventing the anaemia of pregnancy.

S. K. KoN

L. A. Maynard, E. S. Harrison and C. M. McCay. The changes in the total fatty acids, phospholipid fatty acids and cholesterol of the blood during the lactation cycle. J. Biol. Chem. 92, ii, 263-72, July 1931.

The fatty constituents of the blood were studied during the dry period and a succeeding lactation. Following parturition a rapid rise occurred, succeeded by a gradual fall during lactation to the previous low level of the dry period. These changes were noted in total fatty acids, phospholipid fatty acids and cholesterol, the values for each running closely parallel, and approximately following the changes in milk yield, but not milk fat percentage. Although the values may be influenced by food intake, the same changes occurred at a constant level of intake and appeared to be definitely associated with lactation. The study was made on 4 cows, one of which suffered an acute attack of mastitis during the experiment; the changes at parturition were also noted in the case of two other cows.

G. L. Peskett

L. B. Winter. Cellobiose in relation to the mammary gland. J. Physiol. 73, iv, $6 P$, December 1931.

In order to test the possibility of lactose being formed from a $\beta$-glucoside, cellobiose was incubated with various extracts of mammary tissue. Under the conditions of experiment no lactose formation could be detected, nor could any evidence of utilisation of cellobiose be obtained when it was injected into lactating rabbits.

G. L. Peskett

O. Svanberg. Enzymatische Versuche mit Milchdrüsen. (Enzymatic research with milk glands.) Hoppe-Seylers Z. 188, 207-18, 1930. (Milchw. Forsch. 11, ivRef. 73, March 1931.)

The author records experiments in which an attempt was made to imitate in vitro the sugar metabolism of living udder tissue. Preparations of washed and ground mammary gland showed, however, practically no ability to form lactose from glucose, galactose or mixtures of the two. On the contrary, the sugars used, which also included lactose, were almost completely broken down in 21 cases out of 24 , the chief end-product being lactic acid. The effect of various antiseptics was investigated.

Negligible quantities of sugars other than lactose were found to be present in milk, as judged by reduction with Barfoed's reagent.

G. L. PESK ETT

\section{W. B. Cannon and E. M. Bright. A belated effect of sympathectomy on lactation.}

Amer. J. Physiol. 97, ii, 319-21, May 1931.

Removal of the sympathetic nervous system in the dog or cat may cause disturbance of lactation (shortage or absence of secretion) but does not interfere with other reproductive processes.

G. L. PesketT 
F. R. KRzywanek and H. BrÜggemann. Zum Studium der Milchsekretion. II. Der Druckablauf in allen 4 Zitzen des Euters während des Milchentzuges. (Study of milk secretion. II. Release of pressure in all four teats of the udder during the withdrawal of milk.) Milchw. Forsch. 11, iv-v, 371-8, March 1931.

The authors show that the pressure in the individual quarters of the udder falls during milking of those quarters, but it stays relatively constant in the remaining (full) quarters. The conclusion suggested is that there is little, if any, secretion of milk during actual milking and that the udder can accommodate its contained milk at a certain pressure by tonic control of its contractile elements whatever may be its degree of fulness.

G. L. Peskett

J. W. Gowen and E. R. Toвey. Studies on milk secretion. The influence of inanition.

J. Gen. Physiol. 15, i, 45-66, September 1931.

The following changes occurred when cows were deprived of food but allowed free access to water: rapid fall in yield and lactose percentage of the milk, with a rise in total solids, butterfat and ash percentages (the calcium percentage rising out of proportion to other elements of the ash, while phosphorus showed little change); a slight fall in blood sugar and a definite fall in blood calcium percentages in the majority of cases. Administration of parathyroid extract caused a slight rise in the blood calcium and sugar percentages whether the animal received a full ration or not. In all cases there was a tendency for the osmotic pressure of the milk to rise.

It was claimed that "all the changes in milk composition during starvation can be directly related to the simultaneous changes in the blood," e.g. fall in blood sugar causing fall in lactose with a compensatory rise in salts of the milk; rise in osmotic pressure of both blood and milk; independent movement of butterfat as contrasted with the other solids.

(Careful survey of the authors' charts suggests that they hardly warrant the conclusions drawn. Changes in composition of blood and milk seem to have been overemphasised in some places and disregarded in others, especially in the case of lactose and blood sugar percentages and fat and total-solids percentages. Thus reading off values from the curves, decrease in lactose 0.5 per cent. occurred with drop in blood sugar 0.015 per cent. in three instances, 0.007 per cent. in one instance and 0.002 per cent. in another. Similarly a fall of 1.5 per cent. in lactose occurred with a drop in blood sugar of only 0.01 per cent., and a rise of lactose only 0.2 per cent. corresponding to rise in blood sugar 0.02 per cent. As regards fat percentages of the milk, these are by no means independent, since in every case their curve follows that of the total solids per cent. Moreover the figures for osmotic pressures of milk were calculated from protein, ash and lactose percentages (the distribution of ash elements was assumed to be normal although the $\mathrm{Ca}$ and $\mathrm{P}$, the only elements analysed, showed independent movement), and parallel changes in blood were assumed to occur in the cows solely on the basis of previous work of other authors on dogs and rabbits).

G. L. Peskett

\section{J. W. Gowen and E. R. Tobey. On the mechanism of milk secretion. The influence of insulin and phloridzin. J. Gen. Physiol. 15, i, 67-85, September 1931.}

The effects of insulin treatment on milk secretion in the case of starved and unstarved cows were similar to those reported in the previous paper (though more immediate and severe in character) except that the calcium and phosphorus percentages of the milk rose with the ash. In one case a cow was subjected to prolonged insulin shock, the milk solids rose to 37 per cent. (butterfat to 24.8 per cent.) while the yield dropped almost to zero. Subsequently this animal's production returned to 75 per cent. of the normal. In phloridzin treatment combined with starvation there 
was a drop in yield and lactose per cent., a rise in ash per cent. and a rise followed by return to normal in total solids and fat per cent.

The authors consider that these experiments support the conclusions of the previous paper. They interpret the results as showing that in milk secretion a balance is maintained between the osmotic pressure of the milk and of the blood, modification of the blood producing direct and predictable modification of the milk secreted, especially as regards sugar.

(Interpretation of the results is not easy. The significance of the composition of the milk seems to be very doubtful at the very low level of yield reached during the experiments. No observation was made of the blood osmotic pressures, and it is hard to explain the wider variation of milk osmotic pressures which occurred in these experiments in which insulin treatment was the only additional factor. Although it is true that the lactose percentage follows the general trend of the blood sugar percentage, in several instances a definite rise of the former occurred while the values of the latter were falling. Moreover it cannot be said, as the authors claim, that the butterfat percentage is more or less independent of the other constituents, for in every case its curve follows closely that of the total solids per cent.) G. L. Peskzir

\section{DAIRY HUSBANDRY.}

E. W. Fenton and E. D. S. Robertson. Poisonous and milk tainting plants. Symptoms and first aid to stock. Edinburgh and E. Scotland Coll. Agric. N.S. No. 4, 1931.

The pamphlet aims at providing owners of stock with information likely to help them in cases of poisoning of animals or milk taints caused by plants. There are two distinct sections in the booklet, one "Botanical" and the other "Veterinary." The former gives the botanical features of a number of herbs and the latter deals with the symptoms resulting from the various poisonous plants and first aid treatment.

It is doubtful if the booklet bridges the gulf between the scientist and the practical man in the best possible manner, and no very concise statement is given which might help a farmer to decide whether his sick animals or his tainted milk are due to plants or to some other cause.

The two sections appear more convenient to the writers than to the reader, while the choice of sub-headings and terminology is more closely allied to the scientific text books than to the vocabulary of the average farmer.

S. BarTLETS

W. E. Agar. Heredity and milking function. An analysis of the inheritance of milk and butterfat production in Red Poll cattle. J. Dept. Agric. Victoria, 24, i, 1-9, January 1926.

In this article, based chiefly on records of the Red Poll herd of the Victoria State Research Farm, it is concluded that daughters' production is definitely influenced by, but not absolutely determined by the mother. A method of comparing the transmitting qualities of bulls for production is put forward. A brief outline of the method is given below, using fat percentage as a typical inheritable factor:

1. The correlation coefficient between the fat percentage of dams and offspring in the herd records was found to be 0.332 . The regression coefficient of the fat percentage production of daughters relative to their dams was 0.291 . The average production of dams was 4.40 per cent. fat and of daughters 4.30 per cent. fat.

If a single dam's production is 0.40 per cent. fat above the general average (i.e. 4.80 per cent. fat) her daughters on the average may be expected to yield $0.40 \times 0.291$ above the average of all daughters, i.e. $4.30+(0.40 \times 0.291)=4.42$. 
2. Using the above method, the "expected test" of all the daughters of a single bull can be calculated, and it is assumed that this makes an average allowance for the influence of dams on their offspring.

3. The extent to which daughters of a bull exceed or fall below their "expected test" is used as an indication of the transmitting ability of a bull for production.

S. BARTLETT

K. W. D. Campbell. Possible influence of the milkers on the quantity and quality of milk of the individual cow. Agricultural Progress, 8, 114-20, 1931.

Cows milked thrice daily at equal intervals by two milkers per day showed marked variation of milk yield and fat per cent. Cows and heifers were milked for stated periods by one milker only per day.

Under one milker the average milk yield and fat percentage was higher at the morning milking than at any other. Under two milkers the average milk yield had been higher in the morning, but the fat percentage was lower.

Under one milker there were lower variability coefficients for fat percentage, both at successive milkings, and at corresponding milkings on successive days.

The preference cows show for one of two good milkers is marked and shows itself in a more even distribution of both milk and fat over each of two or three milkings.

K. W. D. CAMrpBelL

T. Marchlewski. Certain factors determining the hereditary transmission of an abundant milk production in cows. Paper at Polish Acad. Sci., Cracow, July 7, 1930. (Nature, 126, No. 3191, 1014, December 27, 1930.)

S. W. Mead and W. M. Regan. Deficiencies in rations devoid of roughage for calves.

1. The effect of the addition of cod-liver oil and alfalfa ash. J. Dairy Sci. 14, iv, 283-93, July 1931.

The authors conclude from prolonged experiments on eight animals, that calves can be reared to 19 months of age, and that normal growth can be secured on a ration containing no roughage, providing that cod-liver oil and alfalfa ash are supplied in sufficient quantity. Before the cod-liver oil was given, the animals developed definite symptoms of vitamin A deficiency.

J. Golding

\section{N. HANSSON and N. E. OLOFSSON. Tests of the influence of different fodders on butter} consistency. Kgl. Landibruks-Akad. Handl. Tid. 70, 621-55, 1931. (Chem. Abst. 25, xvii, 4631, September 10, 1931.)

The consistency of butter is affected by the composition of the fodder and the methods of preparation of the butter. Coarse green fodder, clovers and rich grass give a soft butter of high iodine number. Grass as ensilage or hay loses the property of giving soft butter. Coarse winter fodder gives a hard solid butter with little difference between the effects of hay and straw. Roots and cabbages act like straw. The effect of home grown concentrates depends on fat content. Barley gives a hard butter and peas and beans a hard brittle butter, while oats and mixed grain have a less effect. The effect of purchased concentrates depends on the oil content and the oleic acid content of the oil. A food of high oil content with a high iodine value tends to give a soft butter and a food containing oil of low iodine value gives a hard butter. A winter concentrate should contain 5-6 per cent. oil of an iodine value of $100-110$ to give the 
proper consistency to winter butter. Soft butters are given by linseed, sunflower, sesame and rapeseed cakes. Hard butters are given by coconut and palm cakes, cakes low in oil and legume meals. Peanut, cotton seed, soya bean and sunflower meal give butter of medium consistency. A cow reacts within 8 days of commencing to feed a new cake but the response as shown by the composition of the butter is variable from cow to cow, as variations in iodine value of 6-7 are given. Butter consistency is greatly influenced by changes in cooling the cream and working.

W. L. Davies

\section{K. Richter, K. E. Ferber and N. Odaisky. The effect of feeding raw and steamed potatoes on the yield and fat content of milk. Wiss. Arch. Landw. Abt. B, Tierernähr. Tierzucht, 4, 695-715, 1931. (Chem. Abst. 25, xii, 3094, June 20, 1931.) \\ The yield and fat content of milk from cows on a normal diet were compared with those obtained when $12 \mathrm{~kg}$. raw potatoes replaced an equal amount (starch values) of the diet. The fat content did not vary, but the yield of milk decreased 5 per cent. Potatoes were steamed and placed in a silo for 3 months; these potatoes were used in an experiment similar to the one using raw potatoes; the amount of milk decreased 4 per cent., and the fat content dropped from 3.4 to $3 \cdot 14$ per cent. Analysis showed that the steam treatment had no appreciable effect on the chemical composition of the potatoes.}

\section{J. GoLdING and A. H. BLISSETT. Results obtained by feeding small quantities of cows' milk to porkers. Pig Breeders' Annual, 1931-2.}

This paper gives the results of three years' work in which 14 separate experiments involving 162 pigs were conducted. In each experiment the pigs were all fed on a similar basal diet, generally accepted as a good ration for porkers. One lot received half a pint of full cream milk daily from the Institute tuberculin tested herd. This milk contained about 1.32 oz. of dry matter. The control lot of pigs received $2 \mathrm{oz}$. more of the meal mixture to balance the proteins fed in the milk. Although five different rations were fed and although grass, kale and swedes were included, the pigs receiving milk invariably grew more rapidly than the control pigs.

A chart shows that the increase in weight which was only from 1 to 4 per cent. in the summer months, rose to over 10 per cent. in the winter months, giving a good return for the small quantity of milk to which this increase, and improvement in appearance also noted, is attributed.

J. Golding

\section{A. S. Foot, J. Golding and S. K. Kon. A note on the requirements of the pig for the vitamin-B complex. J. Soc. Chem. Ind. 50, xxi, 442-3, May 22, 1931.}

Four litter-mate pigs weighing 32-34 lb. were divided into two similar lots which were kept in metabolic cages on screens. Lot $A$ received a basal diet of polished rice (washed, cooked and dried) light white casein, filter paper pulp and salt mixture. Lot $B$ received a similar diet in which 5 per cent. of dried brewers' yeast replaced equivalent protein in the diet. Ten, and later 20 c.c. of cod-liver oil were administered to each pig. Tested on rats, $\operatorname{diet} A$ was shown to be completely deficient in vitamin-B complex. Diet $B$ produced normal growth. The pigs in lot $B$ also grew well, and now, after four months on the diet, the sow weighs $163 \frac{1}{2} \mathrm{lb}$., and the barrow pig $128 \frac{1}{2} \mathrm{lb}$., and they appear normal and healthy. The pigs in lot $A$ did not grow at all. Their coats became matted and soiled, and their appetite declined steadily. The barrow pig was killed for histological examination after it had been 11 weeks on the diet without showing definite symptoms of vitamin-B deficiency. The sow pig developed a paralysis of the hind limbs after 12 weeks on the diet. This was not relieved by yeast therapy instituted 48 hours after the onset of symptoms. The pig died of septic pneumonia. 
J. M. Evvard, C. C. Culbertson and Q. W. WaLlace. Dried buttermilk for growing and fattening pigs. Iowa Agr. Exp. Sta. Bull. 278, April 1931.

An experiment is reported in which dried buttermilk alone or mixed in varying proportions with tankage is compared with tankage alone as a supplement to a diet consisting of shelled corn (maize) and salt self-fed to fattening pigs.

The addition of dried buttermilk increased the daily live-weight gains in all cases except one, where the percentage of dried buttermilk in the protein supplement was only 10 per cent.

In this experiment the proteins of dried buttermilk were more efficient than those of tankage in balancing the nutritional deficiencies of corn.

Records of water consumption and body measurements of the pigs are given.

A. S. FooT

\section{DAIRY INDUSTRY}

Amending regulations under the Dairy Industry Act (New Zealand). New Zealand J. Agric. 43, ii, 150, August 1931.

Among the amendments to the Dairy Regulations under the above act gazetted on July 30, 1931, may be mentioned the following:

1. The manufacture and export of other than whole-milk cheese is prohibited.

2. The occupier of a dairy is required to provide an adequate water supply and plant adjacent to his dairy for the purpose of washing and scalding or steaming his dairy utensils.

Other regulations deal with the cooling of milk on the farm, the keeping of cheese in the curing room, the temperature of grading stores and the testing of milk.

J. GoLdING

GATES. The Army's milk supply. Journal R.A.M.C. 56, May 1931.

The author discusses the difficulties of the Army's milk supply, particularly in foreign stations and during war.

Two types of dried milk are discussed and compared with condensed milks as now supplied to the services.

The comparison is very much in favour of the dried milk. The author says: "Of the powdered milks those made by the roller process, or better still, if obtainable, those made by the improved roller process are more suitable for military purposes, owing to far better keeping qualities." The short heat treatment involved in the roller process, it is also claimed, does not impair the vitamin content. J. GoLdina

E. F. Eldridge. Disposal studies for milk-products waste. Engin. News Rec. 106, 520-1. (Exp. Sta. Rec. 65, iv, 384, September 1931.)

This paper deals with details of the disposal of diluted dairy waste. J. Golding

O. Kосн. Die Sterilisation der Milchflaschen. (The sterilisation of milk bottles.) Milchw. Zbl. 60, vii, 102-4, April 15, 1931.

Impressed by the importance laid on the sterilisation of milk bottles after they had been washed, as had been observed during a tour in England, the author later carried out comparative tests, the results of which are recorded in this article. The bottles which had been only washed invariably contained large numbers of bacteria, whilst those that had been steamed for 6-8 minutes after washing were, practically speaking, sterile. These findings have been applied in practice, and suitable steaming chests have been designed.

E. R. Hiscox 
A. C. FAY. The preparation, testing and use of chlorine disinfectants. Kansas Agr. Exp. Sta. Circ. 160, July 1931.

A practical guide to the preparation, standardisation and use of hypochlorite disinfectants in the dairy. The methods described are simple, and such as could be applied in a small dairy without the use of elaborate equipment. Suitable dilutions are suggested for various disinfecting purposes, and precautions to be observed in their use are given.

E. R. Hrscox

K. VAS. Das spezifische Gewicht, der Wassergehalt der Bruchkörner und die Rolle des Wärmens (Brennens) bei der Emmentaler Käsebereitung. (Specific gravity, water content of pieces of cut curd and the part played by heat in the manufacture of Emmenthal cheese.) Milchw. Forsch. 11, iv-v, 519-29, March 1931.

The author points out that accurate knowledge of the properties of the cubes of curd is very important because they regulate the water content of the cheese. Instead of leaving judgment to the senses, as is customary, the author uses a "coagulometer" to measure the resistance to pressure shown by the cubes. In general, this property increases with decreasing water content. On the other hand, when kept pressed together through the agency of the cheese coat, the enclosed pieces of curd may develop great resistance, even if they contain considerable moisture.

A close relationship was found to exist between the specific gravity of the cubes and their water content-increase in the former being a good indicator of decrease in moisture. Determinations of specific gravity may be made by suspending in salt solution or in a mixture of paraffin and carbon tetrachloride.

Experiments on these lines showed that long heating of the cheese curd not only results in a marked decrease in water content but also causes the cubes to stiffen and become less sticky. The importance of these effects lies in the fact that these pieces of curd, when pressed together, form a continuous canal system which regulates the rate at which the enclosed whey can leave the cheese through the interstices. L. A. ArLeN

\section{W. H. Udy. Mottled colour in cheese. New Zealand J. Agric. 42, iv, 244-5, April} 1931.

Mottling in annattoed cheese is regarded as being generally due to bacterial reduction, as it occurs most frequently in hot weather. A Gram-negative bacillus has been isolated which bleaches annatto media.

Another important cause of some forms of mottling has been found to be sunlight playing on the annattoed milk in the vat. Hence direct sunlight should not be allowed to shine on the cheese vat.

(This reduction has been shown to be due to the activation of constituents of the milk, especially the olein, which is oxidised while the pigment acts as a hydrogen acceptor. The same phenomenon has been observed in England with various oxidationreduction potential indicators dissolved in the cheese milk.)

J. G. Davis

\section{W. V. PRICE. The influence of sweetened, frozen cream on the development of the} swell in ice cream. J. Dairy Sci. 14, iii, 221-8, May 1931.

Fresh pasteurised cream was divided into four batches, the first batch was maintained at $35^{\circ} \mathrm{F}$. and was regarded as the control, the second was frozen for 48 hours, the third received an additional 10 per cent. of sucrose by weight, while the fourth received an equivalent weight of invert sugar. The last three batches were frozen at $-15^{\circ} \mathrm{F}$. for 48 hours and were then thawed in cold water very slowly. Four mixes were made which differed from each other only in that the cream has received different treatment. The mixes containing frozen, unsweetened cream were slightly 
inferior in whipping qualities to the others which behaved almost identically. Similar results were obtained when the cream was frozen at $-15^{\circ} \mathrm{F}$. for 14 days.

As a result of further experiments on mixes containing egg-yolk frozen with and without invert sugar, it is suggested that the lecithin of the cream and yolk favours swell development, and that sugar has a beneficial influence on the stability of lecithin during freezing at $-15^{\circ} \mathrm{F}$.

F. Procter

\section{REVIEWS}

\section{Sir William Dampier. Dairy Research. A Report to the Empire Marketing Board. Pp. 64. London: H.M.S.O., 1931. 1s.}

A few days before his death, the first editor of the Journal of Dairy Research asked the writer to write a review of Sir William Dampier's monograph, because he was "doubtful of the advisability of its being done by any of us who are actually engaged in research." Elsewhere in his letter he wrote: "I think that few people have realised the magnitude of the problems, that are involved in research in dairying," and he referred to his own brief summary of these on pp. 23-2 of the Annual Report of the N.I.R.D. for 1930 .

There can be no doubt that what Dr W'lliams had in mind was the almost inevitable tendency of research workers to over-emphasise the importance of that section of the field in which they work. Sir William's monograph is an excellent corrective to this. The three questions referred to Sir William Dampier by the E.M.B. in 1929 were:

(1) What is dairy research, i.e. what is the proper line of division between a specialist dairy research institute and the work of other research institutions in the sphere of nutrition, animal diseases and low temperature research?

(2) What is being done in this field in England, Scotland and elsewhere?

(3) What extensions are contemplated or desirable, and what are the most important scientific and practical problems to which attention should be directed?

Important as questions (1) and (3) were in 1929, they are incomparably more important now, when the problem of getting the best value for the expenditure of limited national funds is more insistent, and there will be no regrets that Sir William was not stampeded into delivering a quicker report, for such a report could not have carried the weight of that now presented.

Should anyone be asked to abstract this report, he would be set an impossible task. The author devotes half his space to a review of dairy research now in progress and the rest to answering the other questions referred to him, which are, in effect, to make recommendations to eliminate undesirable overlapping and to indicate what, in his view, seem the directions in which research is most likely to yield important results in the near future. No dairy researcher can fail to be stimulated by reading this report. The more myopic will be helped to see the whole great field of dairy research in better perspective.

G. C. Jones

Ethel Browning. The Vitamins. Monographs of the Pickett-Thompson Research Laboratory. Vol. 1, September 1931. Pp. xxxii + 575. Baillière, Tindall and Cox.

According to the author's introduction, "The original purpose of this monograph was to collect into one volume as much as possible of the existing literature on the subject of Vitamins, and to present to the scientific reader a comprehensive account of the researches which have established the vitamin theory on its present basis...."

The task is an enormous one, and the author has undoubtedly given ample proof 
of great perseverance and tireless labour in collecting, reading and attempting to classify nearly 4000 articles. It must unfortunately be said that she has failed in her "endeavour to weave into a complete pattern those threads which have seemed most important to the continuity of the design." An apparent lack of first hand knowledge of the subject and a not less apparent lack of biochemical training on the part of the author have caused Dr Browning's book to be little more than a confused mass of data and references rather than an orderly presentation of facts and theories. The reviewer has noted in the course of one reading and in the text only, not less that 165 errors, some admittedly of a minor nature. Many of these may be laid at the door of faulty proof reading, but it is hard to pass unnoticed scores of more fundamental errors such as the following which illustrate the shortcomings of the book: on p. 67 the author states that "Carotin is an unsaturated hydrocarbon $\left(\mathrm{C}_{40} \mathrm{H}_{56}\right)$ with a strong affinity for oxygen, being transformed into colourless xanthophyll." On p. 69, when comparing vitamin A and carotene, the author states "both compounds give a blue colour with antimony trichloride, but with vitamin A the colour is permanent, with carotene it is fleeting." On p. 83 one finds the surprising statement that "Vitamin A is the easiest of the vitamins to preserve." On p. 117 it is said that "the meat residue was treated for extraction of casein," while on p. 133 we learn that "When treated with digitonin, vitamin $\mathrm{D}$ forms an insoluble additive compound, and the reaction product is no longer activable." On p. 143 the stock diet of Steenbock is called "diet 2965." The following description of glutathione (pp. 232-3) gives an idea of the chemistry as found in the book: "Glutathion is a dipeptid consisting of a molecule of cystin combined with a molecule of glutamic acid. The formula is a complicated one, the importance being, it appears, the possession of an SH group and the power of reduction of sulphur derivatives, cystin, thioglycocolic and thiolactic acids. The chemical reaction which it undergoes is a to-and-fro one, reduction and oxidation, and it is a typical example of a body which can act in both these ways. The study of its action is indicated in pathological conditions accompanied by disturbance of cellular function." The following heading is found on p. 293: "Vitamin $B_{2}$ (Vitamin $C_{1}$ of American writers)." Page 299 gives "The aqueduct was completely restored, and all possible sources of contamination were removed, while a number of minute pieces of calcium (previously well washed) were introduced into the reservoir and along the channel." "Cod-liver oil is a preventive both for black tongue and pellagra," p. 312; "the antiscorbutic value of fresh limes is very low-about that of lemon juice," p. 328. On p. 409 we learn of the "increasing tendency to regard vitamins as inorganic chemical bodies," while on p. 426 we are asked to believe that "the loss of appetite" (italics of the reviewer), "Ioss of weight and fall of body temperature, which are three of the most characteristic features of vitamin $B_{1}$ deficiency, have all been attributed to inanition rather than to a specific effect af vitamin $B_{1} . "$

Such examples could be greatly multiplied, as nearly every page of the book brings us a fresh surprise. Apart from such errors, it is often evident that Dr Browning does not understand the subject she discusses. To quote only. a few instances, this is apparent in the paragraphs on the relation of vitamins to protein intake, pp. 27-9, the discussion of the mechanism of formation of vitamin $\mathrm{D}$ on p. 130, and the explanation of refection on p. 427 .

The chapter on the quantitative estimation of vitamins, pp. 48-61, is full of inaccuracies and omissions-e.g. the rachitogenic diet, diet 2965 of Steenbock, and the simple scurvy-producing diet of the Lister Institute are not mentioned at all. The compositions of standard diets for the production of vitamin $A$, vitamin $B_{1}$ and vitamin $B_{2}$ deficiencies are not given and the estimation of vitamin $E$ is dismissed in a few inadequate words.

The extensive tables showing the vitamin content of foodstuffs could have proved 
quite useful, but unfortunately here also inaccuracies are found, for example, irradiated yeast is allotted 2 crosses for its vitamin $\mathrm{D}$ content while cod-liver oil and irradiated butter are given three where it is known that irradiated yeast is about 75 times as potent as good cod-liver oil.

The extensive bibliography loses much of its value on account of several references being given to the same author and year with no distinguishing marks in the text.

S. K. KoN

W. Clayton. Colloid aspects of food chemistry and technology. Pp. viii +571 (1-446 text, 446-571 glossary, bibliography and index). London: J. and A. Churchill, 1932. 36s.

Up to the present no attempt has been made to survey the field of food chemistry with reference to those physico-chemical aspects which come within the range of modern colloid chemistry, and this volume seeks to fill this gap in textbook literature and may be taken as a guide to colloid problems which may be unfamiliar to food chemists who have not specialised in colloid chemistry.

The text of thirteen chapters commences with an historical survey embodying the scope of modern colloid concepts followed by well-arranged comprehensive treatment of the industrial application of these concepts to all branches of food technology including gums, proteins, cereals, milk and its products, sugar fruit preserves, brewing, cold storage of animal and vegetable foods, and sewage. The colloid aspects of nutritional chemistry are also discussed.

Milk and its products are treated fully from the physical and physico-chemical aspects in 87 pages of condensed descriptive material. This section is well supported by references and will be useful for the research worker requiring either condensed information on special physical points or indications as to where the problems have been elaborated in the journals. Special mention must be given to the treatment of milk, cream and butter, as emulsions in which theories on the composition of the fat-globule membrane and the state of water in butter are discussed fully.

Industrial processes such as pasteurisation, homogenisation and cream whipping are included, and the coagulation of milk, especially by rennet action, and the manufacture of the various types of casein are fully described. Other sections include the physical chemistry of cheese, ice cream and milk coagulation in the stomach.

The book can be recommended as a concise source of up-to-date information for the dairy research worker, and to the teacher requiring material for advanced students. The additional advantage of having at hand information on cognate problems in other branches of food chemistry is evident. The bibliography is extensive, references both at the foot of the pages and collected into a separate section ( 96 pages), being supplied, and complete author and subject index are also included.

W. L. Davies 


\section{STATISTICS}

\section{Number of Dairy and Other Cattle.}

THE following table shows comparative figures of the dairy herd, and of other cattle, in the principal countries within the British Empire in which dairying is of major importance. The figures are in each case the latest available, and are generally of a preliminary nature, but it should be noted that the estimates of livestock relate to different dates in the various countries. It should also be noted that classification of cattle into the dairy herd and other cattle is not a matter of uniform practice throughout the Empire, but the figures give a fairly accurate indication of the extent of the dairy herd and of any change in comparison with the preceding census.

\begin{tabular}{|c|c|c|c|c|}
\hline \multirow[t]{2}{*}{ Countries } & \multirow[t]{2}{*}{ Year* } & $\begin{array}{c}\text { Cows and } \\
\text { heifers in } \\
\text { milk or } \\
\text { in calf }\end{array}$ & $\begin{array}{l}\text { Other } \\
\text { cattle }\end{array}$ & $\begin{array}{l}\text { Total } \\
\text { cattle }\end{array}$ \\
\hline & & 000 head & 000 bead & 000 head \\
\hline \multirow[t]{2}{*}{ England and Wales } & 1931 & 2790 & 3274 & 6,064 \\
\hline & 1930 & 2675 & 3175 & 5,850 \\
\hline \multirow[t]{2}{*}{ Scotland } & 1931 & 454 & 755 & 1,209 \\
\hline & 1930 & 453 & 783 & 1,236 \\
\hline \multirow[t]{2}{*}{ Northern Ireland } & 1931 & 258 & 422 & 680 \\
\hline & 1930 & 256 & 417 & 673 \\
\hline \multirow[t]{2}{*}{ Irish Free State } & 1931 & 1300 & 2729 & 4,029 \\
\hline & 1930 & 1311 & 2727 & 4,038 \\
\hline \multirow[t]{2}{*}{ Canada } & 1931 & 3513 & 4478 & 7,991 \\
\hline & 1930 & 3683 & 5254 & 8,937 \\
\hline \multirow[t]{2}{*}{ Australia } & 1929-30 & 2465 & 8737 & 11,202 \\
\hline & $1928-29$ & 2467 & 8834 & 11,301 \\
\hline \multirow[t]{2}{*}{ New Zealand } & 1931 & 1602 & 2479 & 4,081 \\
\hline & 1930 & 1441 & 2329 & 3,770 \\
\hline \multirow[t]{2}{*}{ Union of South Africa } & 1930 & \multirow{2}{*}{\multicolumn{2}{|c|}{$\begin{array}{l}\text { Not available } \\
\text { Not a vailable }\end{array}$}} & $10,574 \dagger$ \\
\hline & 1929 & & & 10,518 \\
\hline \multirow[t]{2}{*}{ Kenya } & 1931 & 71 & 166 & $237 \ddagger$ \\
\hline & 1930 & 68 & 159 & 227 \\
\hline
\end{tabular}

\footnotetext{
* Estimates relate to June except New Zealand (January 1), South Africa (August 31), Kenya (February 28, 1931 and July 31, 1930); for Australian States estimates refer to December 31 except New South Wales and F.C.T. (June 30 following).

$\dagger$ Including 6,668,000 cattle on farms owned by Europeans.

$\ddagger$ Relates solely to European-owned cattle; the estimated number of native-owned cattle in Kenya was 4,966,000 on July 31, 1930.
} 


\section{Trade in Datry Produce.}

The following tables give details of the trade in butter and cheese of the principal countries handling these products during 1931, with comparative figures for 1930. The particulars are based on information published by the International Institute of Agriculture, Rome, brought up to date, where necessary, from official sources.

Exports and imports of butter.

\begin{tabular}{|c|c|c|c|c|c|}
\hline \multirow{2}{*}{\multicolumn{2}{|c|}{ Countries }} & & & & \\
\hline & & 1931 & 1930 & 1931 & 1930 \\
\hline Exporting countries & & $000 \mathrm{lb}$. & $000 \mathrm{lb}$. & $000 \mathrm{lb}$. & $000 \mathrm{lb}$. \\
\hline Austria $\ldots$ & $\ldots$ & 2,862 & 4,112 & 1,565 & 545 \\
\hline Denmark ... & $\ldots$ & 378,429 & 372,558 & 1,596 & 1,389 \\
\hline Estonia $\ldots$ & $\ldots$ & 31,844 & 31,010 & - & - \\
\hline Irish Free State & $\ldots$ & 42,307 & 58,766 & 3,324 & 3,391 \\
\hline Finland $\ldots$ & $\ldots$ & 38,367 & 37,726 & - & 7 \\
\hline Hungary ... & $\ldots$ & 4,065 & 3,430 & 117 & 40 \\
\hline Latvia $\quad \ldots$ & $\ldots$ & 41,313 & 40,631 & 24 & 49 \\
\hline Lithuania... & $\ldots$ & 19,191 & 16,219 & - & - \\
\hline Netherlands & $\ldots$ & 72,660 & 92,394 & 8,887 & 4,396 \\
\hline Norway ... & $\ldots$ & 1,629 & 236 & 379 & 1,530 \\
\hline Poland $\ldots$ & $\ldots$ & 27,470 & 26,714 & 31 & 29 \\
\hline Sweden $\ldots$ & $\ldots$ & 43,162 & 58,857 & 40 & 18 \\
\hline U.S.S.R. ... & $\ldots$ & 68,027 & 23,198 & - & - \\
\hline Canada $\ldots$ & $\ldots$ & 10,681 & 1,179 & 2,822 & 38,605 \\
\hline U.S. America & $\ldots$ & 2,004 & 2,967 & 1,883 & 2,471 \\
\hline Argentina & $\ldots$ & 47,948 & 51,156 & - & - \\
\hline India $\quad \ldots$ & $\ldots$ & 364 & 551 & 344 & 282 \\
\hline Syria and Leban & & 1,817 & 2,161 & 344 & 172 \\
\hline Australia ... & $\ldots$ & 208,924 & 126,411 & - & 2 \\
\hline New Zealand & $\cdots$ & 221,083 & 208,170 & - & - \\
\hline Importing couniries & & & & & \\
\hline Belgium ... & $\ldots$ & 2,756 & 2,648 & 41,562 & 22,633 \\
\hline Czecho-Slovakia & $\ldots$ & 661 & 694 & 4,107 & 714 \\
\hline France $\quad \ldots$ & $\ldots$ & 11,036 & 12,106 & 40,836 & 12,921 \\
\hline Germany ... & $\cdots$ & 269 & 575 & 220,950 & 293,560 \\
\hline Greece $\quad \ldots$ & $\ldots$ & - & - & 2,059 & 1,420 \\
\hline Italy & $\ldots$ & 1,290 & 1,843 & 6,188 & 3,115 \\
\hline Spain $\quad \ldots$ & ... & 88 & 161 & $121^{\circ}$ & 328 \\
\hline Switzerland & $\ldots$ & 20 & 40 & 23,358 & 18,794 \\
\hline United Kingdom & & 40,228 & 20,514 & 903,969 & 764,019 \\
\hline Ceylon $\quad .$. & $\cdots$ & - & - & 642 & 723 \\
\hline Java and Madurs & & - & - & $7,862^{*}$ & $7,158^{*}$ \\
\hline Japan $\quad \ldots$ & ... & 一 & - & 231 & 611 \\
\hline Algeria $\quad \ldots$ & ... & $66^{*}$ & $73^{*}$ & $4,237^{*}$ & $3,040^{*}$ \\
\hline Egypt $\quad \ldots$ & ... & $44^{*}$ & $42^{*}$ & $1,918^{*}$ & $2,156^{*}$ \\
\hline Tunis $\quad \ldots$ & ... & 9 & 13 & 930 & 829 \\
\hline
\end{tabular}


Exports and imports of cheese.

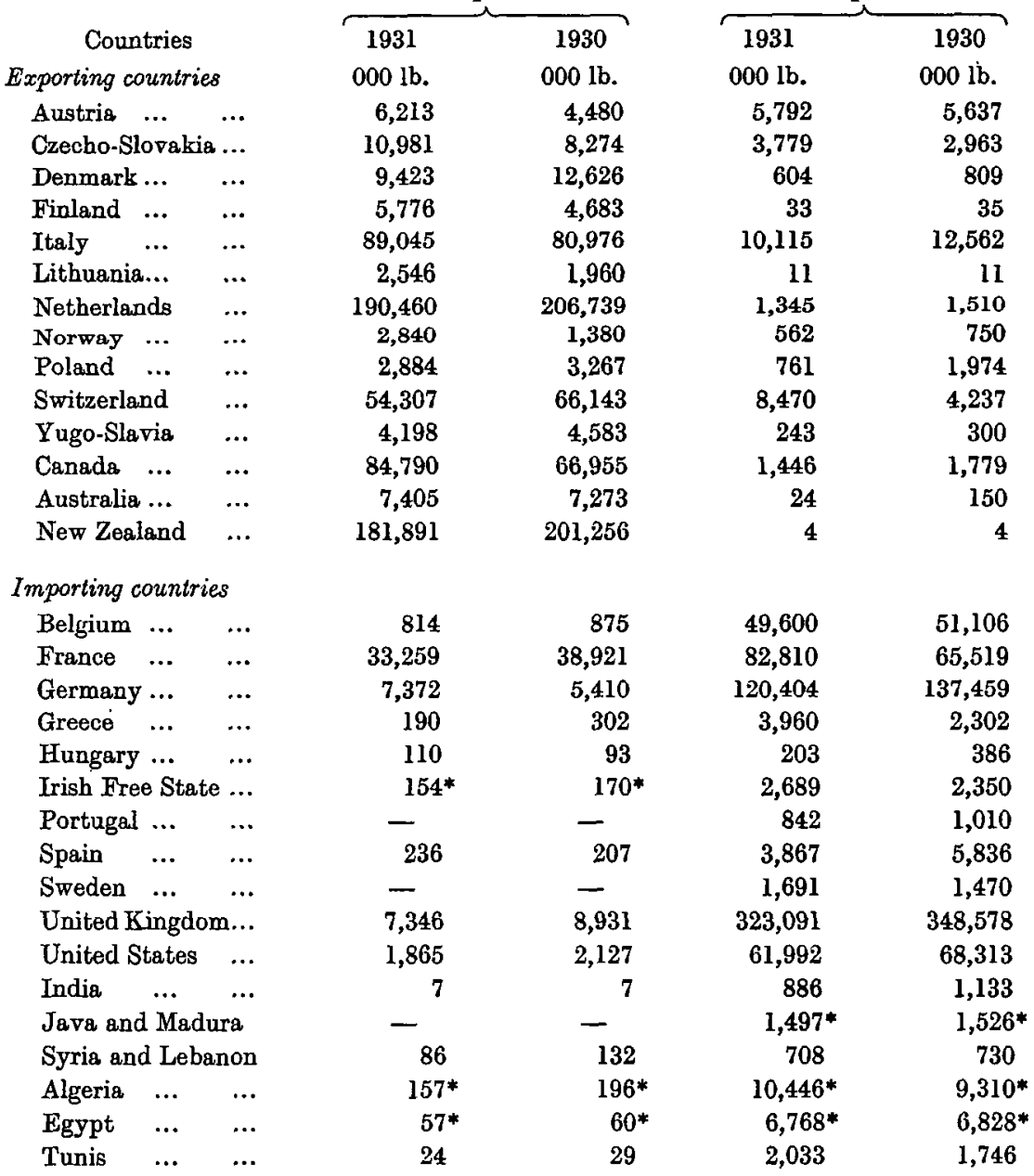

* From January 1 to November 30 only. 